\title{
Reconstructing a Deuteronomistic Athaliah in the (South) African context: A critique of the patriarchal perception of women
}

\author{
Author: \\ Ndikhokele Mtshiselwa ${ }^{1}$ \\ Affiliation: \\ ${ }^{1}$ Department of Biblical and \\ Ancient Studies, University of \\ South Africa, South Africa \\ Correspondence to: \\ Ndikhokele Mtshiselwa \\ Email: \\ mtshivnn@unisa.ac.za \\ Postal address: \\ PO Box 392, Pretoria 0003, \\ South Africa

\section{Dates:} \\ Received: 17 Sept. 2014 \\ Accepted: 15 Feb. 2015 \\ Published: 01 June 2015 \\ How to cite this article: \\ Mtshiselwa, N., 2015, \\ 'Reconstructing a \\ Deuteronomistic Athaliah in \\ the (South) African context: \\ A critique of the patriarchal \\ perception of women', \\ Verbum et Ecclesia 36(1), Art. \\ \#1384, 8 pages. http://dx.doi. \\ org/10.4102/ve.v36i1.1384

\section{Copyright:} \\ (C) 2015. The Authors. \\ Licensee: AOSIS \\ OpenJournals. This work is \\ licensed under the Creative \\ Commons Attribution \\ License.
}

Read online:
Angie Motshekga, the president of the Women's League of the ruling African National Congress (ANC 2014), is reported to have said that 'South Africa is not ready to have a female president ...' What is perturbing about her statement is the presupposition that South-African society perceives women as presently incapable of leading the country as president. Given the variety of literature on female empowerment in South Africa, Motshekga's statement comes both as a disappointment and a disempowering assertion as it does not exhibit a clear attempt to address patriarchy. This article re-interprets the character of Athaliah in 2 Kings 11 and probes it for the empowering possibility that it offers the women of South Africa. It argues that Athaliah was a politically astute queen and that the scarcity of female rulers in ancient Israel confirms the patriarchal bias against women. Thus, drawing from the reconstructed character of Athaliah and from the leadership demonstrated by selected women politicians against a patriarchal paradigm that is part of African cultures, the article submits that the perception of women as capable of leading South Africa as president is justified.

Intradisciplinary and/or interdisciplinary implications: The present article partly responds to Angie Motshekga's statement that 'South Africa is not ready to have a female president ...' Thus, drawing from the insight in the fields of the Old Testament, social sciences and gender studies, this article submits that the perception that women are capable of leading South Africa as president is warranted.

\section{Introduction}

In her criticism of the way in which the perturbing harsh reality of the oppression of women is often minimised in Africa, Oduyoye (2002) remarks:

The 'our women are not oppressed' stance is an ideological statement that emanates from Africa ad extra. It seeks to render feminism a non-issue for Africa. The rest of the world is expected to believe this, while the women of Africa are expected to collaborate with this essentially male propaganda. (p. 75)

Interestingly, this remark highlights a view (especially when considered in the context of SouthAfrican politics) that sees African women as liberated when in fact many of them are not. Angie Motshekga's statement that 'South Africa is not ready to have a female president' (Hunter 2013; Seale 2013) suggests that patriarchy prevails in (South) African ${ }^{1}$ politics and confirms Oduyoye's view. However, first and foremost, both the context of such a statement and the reasons that Motshekga gave for articulating the preceding statement are worth mentioning. Motshekga's statement was articulated as the opinion of the African National Congress Women's League (ANCWL) in the context of the discussion on the possible presidential candidates for South Africa. The statement that 'South Africa is not ready to have a female president' is set against the question posed by the ANC woman veteran and South Africa's ambassador to Italy, Thenjiwe Mtintso (2012:7): 'Has there never been a politically astute, capable, competent woman of integrity ready and willing to lead the ANC in one hundred years?' Following this question, the ANCWL held that it was not yet time for South Africa to have a woman president instead of redressing the ANC's continued reliance on men to lead the party and the country as Mtintso argued. As such, in the light of the ANCWL's position, the ANC-led government seems to be an institution of male dominance, rule and privilege in which women continue to be seen as subordinates to male presidents. Thus, ironically, women seem to be oppressed in a country that has declared its allegiance to democratic principles. Such an irony will further be explored later. Suffice it to say that the situation across the continent is not much different. 
As Baldauf (2012) rightly points out, in the 20th and 21st century, only three women have assumed the office of head of state or president in Africa, namely Empress Zauditu ${ }^{2}$ of Ethiopia (1916), Ellen Johnson Sirleaf of Liberia (2006) and Joyce Banda of Malawi (2012-2014). This evidence confirms that patriarchy indeed reigns in Africa's political arenas and that women often assume or are allocated secondary roles as Oduyoye (2005:10) points out. Thus, as Oduyoye argues, feminism cannot be seen as a non-issue in Africa. Like Oduyoye, Snyman (2010:806) also sees patriarchy as a challenging social situation where women often find themselves in a subordinate position. In addition, the dominance of imperialistic masculinity in (South) African politics seems to confirm the subordinate position that has been allocated to women.

On a hermeneutical level, this article builds on the contribution made by South African scholars on African biblical hermeneutics. Significantly, Snyman (2011:24) is sympathetic to the approach of foregrounding the modern context that provides an impetus for an understanding of the biblical text. In line with Snyman, West (2014:2) advocates for a dialogue between the modern context and the biblical text. This means that interaction between the context and the biblical text is recommended rather than merely drawing exact comparisons. Furthermore, concerning such interaction, Masenya (ngwan'a Mphahlele) (2012:458) decisively argues that the starting point of the interaction with the biblical texts - interaction that seeks to impact the modern contexts is the struggle of oppressed people. Following Snyman, Masenya (ngwan'a Mphahlele) and West, the story of 2 Kings 11 is read from the perspective of the challenge of oppression that is apparent in the (South) African context, pointed out above. The text presents the story of a woman, Athaliah, who became a head of state. On the one hand, particularly from the African biblical-hermeneutics point of view, the evidence of a woman head of state in the Old Testament suggests the potential for female empowerment in a context where a woman has never been president such as South Africa. On the other hand, the historian's portrayal of Athaliah as a murderer presents difficulties. As a result, one is hesitant to use 2 Kings 11 as a liberative text to advocate for a female president in South Africa. This article does not intend to argue that 2 Kings 11 displays an element of patriarchal bias towards Athaliah per se. However, as it will be argued later, the receptions of Athaliah that only focus on her negative actions and disregard her positive works, which are evident in her political astuteness, are unreasonable. Given the fact that Athaliah was an astute leader in ancient Israel, the following question comes to mind: Should Athaliah be viewed merely as a bad leader who was incapable of leading a state? Correspondingly, is the patriarchal perception that women are incapable of leadership such as the president of (South) Africa justified? Based on academic literature and a reconstructed character of Athaliah and set against a system of patriarchy, this article concludes that women should be 2.The name Zauditu is sometimes rendered as Zawditu or Zewditu (Adejumob 2007:189) viewed as capable of leading South Africa as president. The discussion will follow the outline below:

- patriarchy, women and politics in (South) Africa

- echoes of women's empowerment amidst patriarchy

- a gender-conscious reading of 2 Kings 11.

\section{Patriarchy, women and politics in (South) Africa}

The statement of the ANCWL that 'South Africa is not ready to have a female president' not only alludes to the perception of women as presently incapable of leading state, but it also shows the manner in which the role of the male as primary authority figure is both central and dominant in SouthAfrican politics and society. Thus, the manifestation of the system of patriarchy in South Africa is noticeable in such a statement. Lerner (1986) defines patriarchy as follows:

... the manifestation and institutionalisation of male dominance over women and children in the family and the extension of male dominance over women in society in general. It implies that men hold power in all the important institutions of society and that women are deprived of access to such power. (p. 239)

That male dominance over women within the South African society shows the manifestation of patriarchy is a point that cannot be denied. In this society, the male figure continues to hold authority over women regardless of the strides taken by government towards gender equality. Masenya (ngwan'a Mphahlele) (2011:94) commends the strides toward gender equality in the appointment of women in high-ranking political positions as will be shown below. At stake here is not the idea that the South-African government subscribes to patriarchy but that the South-African society is still patriarchal. In her critique of the traditional Sepedi kgoro - a meeting place of men, lineal group and clan - Masenya (ngwan'a Mphahlele) (2011:93) notes the patriarchal culture amongst the Bapedi as women are still not allowed to participate actively in matters pertaining to the kgoro. In other words, the society still does not allow women to lead. In the light of Lerner's attractive definition of patriarchy as well as the fact that South Africa has never had and still does not have a female president, it would be reasonable to argue that patriarchy is also expressed in the statement that 'South Africa is not ready to have a female president'. In other words, Motshekga's statement is appealing as it suggests that South-African society is still trapped in the patriarchal paradigm, hence it is not yet ready to have a female president. Such a suggestion confirms the manifestation of the patriarchal system, which continues to privilege and place men in a position of power over women. In such a system, women are clearly perceived and rendered as incapable of being in a position of power when compared to their male counterparts. However, Motshekga's statement comes both as a disappointment and a disempowering statement as it is not clearly set against patriarchy as observed earlier. Had Motshekga's statement questioned the continuing dominance of men in the ANC and the reliance on men to lead the party, as Mtintso (2012:7) has done, no doubt such a statement would have exhibited 
an attempt to address patriarchy. However, the statement does not refute patriarchy and neither does it suggest that there are politically astute, capable, competent women of integrity ready and willing to lead the ANC, as Mtintso would argue. As will be shown below, there are politically astute women in South Africa, but the patriarchal society is not ready for them to take the lead. As such, it is reasonable to argue that the South-African community remains trapped in the patriarchal system as such a community, particularly the ANCWL, does not refute the continuing authority of a male figure as president over women who may be equally capable to lead the country. Worthy of note is the fact that there is no convincing evidence to claim that the ANCWL subscribes to a patriarchal agenda. Instead, the statement of the ANCWL that South Africa is not ready to have a woman president merely reflects the sentiments in society.

South Africa has one of the most (or maybe the most) liberal constitutions in the world. That means that the SouthAfrican government actively imposed legislation to enhance gender equality in the workplace, specifically in government structures. To that end, clauses 3.2 (a), 4.(1)(c), 4.4 and 7.(2) that are contained in the Women Empowerment and Gender Equality Bill set out to promote women empowerment, equal representation and meaningful participation of women in all decision-making positions and structures (Republic of South Africa 2013:5, 6, 14, 15). However, the perception that South Africa is not ready for a female president, coupled with the perception that women are presently incapable of leading states as well as the scarcity of women heads of states in (South) Africa, suggest that the implications of this bill for heads of state have not yet been implemented. This is why I hold the view that the South-African community is trapped in a patriarchal paradigm that places men in a position of power and authority over women.

Furthermore, based on the scarcity of women heads of state in Africa in modern history, there is an apparent narrative about the incapability of women to lead a country in (South) Africa. Not only does such scarcity suggest that African societies perceive men as better presidential candidates compared to their women counterparts, but it also illustrates the system of patriarchy in which men are placed in a position of authority and dominance over women as Lerner would argue. Before probing that narrative, it would be helpful to consider the success stories of the only three women heads of state in Africa's modern history. According to both Adejumobi (2007:65) and Tesfu (2014), firstly, Empress Zauditu of Ethiopia abolished the slavery which was instituted by the Italians, and she maintained political stability in Ethiopia during her rule. Secondly, in recognition of her achievements, Ellen Johnson Sirleaf received a Noble Prize in 2011 for promoting reconciliation in Liberia (Cowell, Kasinof \& Nossiter 2011). Thirdly, President Joyce Banda of Malawi received the African Prize for Leadership for the Sustainable End of Hunger as well as the International Award for Entrepreneurship Development by the African Federation of Woman Entrepreneurs and Economic Commission for
Africa (Horsfield 2013). It is therefore evident that, outside of South Africa, that is, in other African countries, women have proved to be reliable and successful heads of state. However, in South Africa, no woman has ever assumed the office of president even though one cannot dispute the fact that there are women in South Africa who are capable of leading the country.

In South Africa, a woman, Phumzile Mlambo-Ngcuka, was once the deputy president in 2005. Her competence as deputy president is proven by her subsequent appointment as the Executive Director of the United Nations Entity for Gender Equality and Empowerment of Women (UN Women) by the United Nations. Her appointment illustrates the ability of women to productively assume leadership roles. Furthermore, the leadership ability of Nkosazana Dlamini-Zuma has been recognised. The media has elevated the credibility of Dlamini-Zuma as a leader which has made her popular in some circles not only in South Africa but on the African continent. Malala points out that when she was elected as the head of the AU, Dlamini-Zuma was already one of the South-African government's best-performing politicians (Malala 2012; cf. Murithi 2012:662):

But in 2009, when she was appointed home affairs minister, she became a darling of the country and turned a corrupt and constantly derided department into one of the countries' most efficient ... and her election has been hailed as a milestone ... (p. 1)

Malala's remark suggests that Dlamini-Zuma is a capable leader who might be able to assume the role of a head of state. The fact that she is already playing a leadership role at both continental and international level by being in consultation with African heads of state in her present role shows her acquaintance with what it takes to lead a state. It is disappointing that, even though women are clearly leaders at national, continental and global level, South-African society continues to disregard them as potential presidential candidates. Women are leaders of political parties and therefore eligible to be the country's president, but they continue to be restricted by patriarchal cultures in the SouthAfrican society which are reflected in the statement made by Motshekga. Such a noticeable restriction lends credence to the claim that patriarchal chains continue to bind and restrict women from being president in South Africa.

It cannot be disputed that the history of South Africa and particularly that of the ANC not only validates Angie Motshekga's statement, but it also throws light on the evidence of patriarchy because the ANC has never had a female president since its inception. According to the ANC (2014), John Dube (1912-1917) was the first leader of the ANC, followed by Sefako Makgatho (1917-1924), Zacharias Mahabane (1924-1927), Josiah Gumede (1927-1930), Pixley ka Seme (1930-1936), Zacharias Mahabane (1936-1940), Albert Xuma (1940-1949), James Moroka (1949-1952), Albert Luthuli (1952-1967), Oliver Tambo (1967-1991), Nelson Mandela (1991-1997), Thabo Mbeki (1997-2007) and Jacob 
Zuma (2007 to date). All these leaders were men, clearly showing that the leadership of the ANC has been dominated by men. As noted above, there is no doubt that there are women who are politically astute and capable of leading South Africa. Since the election of the ANC male leaders reflects the voice of the people, it is clear that South African society is patriarchal. If the society of South Africa continues to be patriarchal, South Africa will never have a woman president. This is a lamentable fact.

\section{Blowing the trumpet louder?: Echoes of women's empowerment amidst patriarchy}

Hendricks Jr. (2005:76-78) explains that blowing the trumpet refers to the prophetic pronouncement of liberation which has at heart both the concern for the oppressed and the quest for their liberation (cf. Lv 25:9-10). On the practicality of blowing the trumpet, Cone (2005:62) raises a critical question: 'Why is it that the Black church can be so progressive on race and so conservative when dealing with patriarchy and homophobia?' The question seeks to address the oppression of women under patriarchy and demonstrates what blowing the trumpet means in a context where women are disempowered. The concept of 'blowing the trumpet' will therefore be used in this article in relation to the voices of the (South) African women scholars against patriarchy. Mercy Oduyoye, Madipoane Masenya (ngwan'a Mphahlele) and Musa Dube, amongst others, have convincingly blown the trumpet on the unjust patriarchal treatment of women in Africa. They echoed statements that both criticised patriarchy and empowered women in the context of various forms of injustice experienced by women. For example, on the imperialism of masculinity in Africa, Oduyoye (2005) points out a discrepancy with the view that women are inferior to men and advocates that both men and women be considered as equals:

Women are persons-in-communion, not persons who 'complete' the other. There are female souls and there are male souls. We may need to reorient our thinking so that we see communion as a relationship devoid of hierarchical relations and powerseeking. When we have learned more about our humanity perhaps we will also be able to understand what God is telling us about divinity. (p. 23)

At issue here is the power dynamics which reveals that, on the one hand, men often regard women as below them in terms of hierarchical relationships. On the other hand, women often think of themselves as less important and less valuable than men. Hence, Oduyoye argues that women be considered as 'persons-in-communion' with men instead of as below men.

Masenya (ngwan'a Mphahlele) argues that women and men be regarded as equals. To highlight the reason for her reading of Steve Biko, she asks, 'How many African women today still negate progressive liberationist theologies/philosophies geared to enabling them to affirm their full humanity as equal human beings?' (Masenya [ngwan'a Mphahlele] 2008:119). She admits that Biko was certainly no advocate of the rights of Black women per se. However, she proceeds to build on Arnold's inference that Black women fell within the compass of his broader concern for the humanity of Black people. Masenya (ngwan'a Mphahlele) calls for the affirmation of women in her appraisal of Steve Biko, noting the following (Masenya [ngwan'a Mphahlele] 2008; cf. Arnold 1977:21-22):

... noble qualities of this great son of Africa should be aspired to and emulated by present-day African women even as we continue to struggle for full affirmation of African female humanity. (p. 119)

She (Masenya [ngwan'a Mphahlele] 2008) reasons as follows:

Biko's call to South African peoples to embrace the affirmation of all human beings irrespective of their skin colour should inspire African women to challenge the underlying perception that the norm is exclusively white. Maleness, too, is not the norm. The latter category, though, seems not to have been part of Biko's vocabulary. The perception that whiteness and maleness are normative should be resisted by African women, as it challenges their worth as equal human beings. (p. 122)

That there is a need for women to affirm their intrinsic worth as equal to men is both a liberative and empowering reading of Steve Biko. However, Masenya (ngwan'a Mphahlele)'s reading also has its limitations. Perhaps due to the limited scope of her contribution, she does not give much attention to how her African-conscious female reading of Steve Biko could empower women who, according to her, continue to be at the lowest rung of the political ladder in South Africa (Masenya [ngwan'a Mphahlele] 2008:122). One is hesitant to agree fully with Masenya (ngwan'a Mphahlele) on the point that women are at the lowest rung of the political ladder in South Africa. The representation of women in politics, for instance, in the ministerial cabinet has improved. There are 20 male and 15 female cabinet ministers as well as 20 male and 16 female deputy ministers in President Zuma's cabinet today (Zuma 2014). Nonetheless, the question posed by this article sets out to fill the gap, namely to blow the trumpet louder for the empowerment of women in politics, particularly with regards to the presidency.

The view that women continue to be at the lowest rung of the political ladder in South Africa shows how South-African society is hierarchical. In a hierarchical context in which human beings are often assigned their place in the society, Masenya (ngwan'a Mphahlele)'s (2004:116) argument that women are at the lowest rung of the political ladder confirms the idea that society places males at the top of the social scale with women at the very bottom. That a woman has never been elected as the president of the ANC and the country not only shows how women have not been at the top in the South-African hierarchical context but equally validates the argument that South-African society is patriarchal. As Fiorenza (2014:11) excellently perceived, from a hierarchical point of view, the position of domination that renders males as having power over their women counterparts may be viewed as oppressive to women. The persistent position of 
being on the top, on the part of men, in South-African society is therefore an unjust one as it continues to place women at a lower position compared to that of men.

On her part, Dube (1996:37-59, 1999:213-228, 2000:102-109, 2003:60-76) argues that African women experience 'double colonisation' by patriarchy and imperialism and that one cannot be asked to fight against one without the other. Although she brings up the issue of imperialism in the context of the political space, namely the colonisation of African countries, Dube does not address the patriarchal treatment of women in the political space per se as it relates to the subject of presidency.

In view of the persistent imperialism of masculinity in (South) African politics, it appears on the surface that scholars such as Oduyoye, Masenya (ngwan'a Mphahlele) and Dube have not blown the trumpet against the oppression of women loud enough. Their voices against patriarchy do indeed sound in clear and convincing ways that fundamentally seek to empower women in Africa. However, there is little evidence of criticism against the ways in which masculinity has dominated politics in (South) Africa or the question why modern Africa has produced only three women heads of state with none in South Africa. Thus, it is important to blow the trumpet louder, specifically to address such a situation, and to do that, an Old Testament narrative is considered.

\section{A gender-conscious reading of 2 Kings 11: The elevation of Athaliah in the Deuteronomistic history}

Botta (2014:116) defines a 'gender-conscious' reading as an analysis of a biblical text which expands the traditional method of reading the Bible by taking into consideration the gender of the authors and the characters in the text that are read. In this analysis, the gender location of the modern reader as well as the gender location of the authors contribute to the interpretation of the Bible. A gender-conscious reading is one which does not turn a blind eye to the possible evidence of patriarchy in ancient texts. It is also a reading that investigates the possible oppressive way in which women are portrayed in a particular text. In other words, a gender-conscious reading seeks to elevate the status of women in ancient texts. As such, the text under investigation in this article is 2 Kings 11. ${ }^{3}$ The Deuteronomistic History (DH) presents Athaliah as the daughter of both Ahab (2 Kgs 8:18) and Omri (2 Kgs 8:26). She is also called the mother of Ahaziah, the king of Judah, in 2 Kings 8:25-26 (Olojede 2013:162). Although an issue of contention in Old Testament scholarship, the discrepancy around whether Athaliah's father was Ahab or Omri will not be addressed in this article. In 2 Kings 11, the Deuteronomist historian writes that '... now when Athaliah, Ahaziah's mother, saw that her son was dead, she set about to destroy all the royal family' (2 Kgs 11:1). Joash, her grandson, was included in the plot (2 Kgs 11:2). Olojede (2011:120) notes that

3.The New Revised Standard Version's (NRSV) translation of the Hebrew text will be used in the present article.
Joash, the little prince, was hidden from Athaliah's sword. This observation tallies with the textual evidence in 2 Kings 11:2 that Athaliah planned to kill Joash. For her part, Olojede is thus clear in her view of Athaliah as evil. Puzzled by the historical narrative that Athaliah wanted to kill her grandson, Lee (2004) argues as follows:

As the gebirah, (gebirâ a queen mother) ${ }^{4}$ she had and would continue to have vast political power, especially if her grandson was on the throne. So the Deuteronomistic historians' report that Athaliah wanted to kill Joash would not be plausible. (p. 115)

However, Lee's argument does not necessarily hold as people with power often want more power. For example, Knight (2011:235) correctly points out that the priestly class often sought and attained more power. That the priest Jehoiada commanded the captains who were set over the army' to seize Athaliah's power by eliminating her (cf. 2 Kgs 11:15) supports the preceding claim.

On the implausibility of the narrative that Athaliah wanted to kill her grandson, Fritz (2003) also remarks:

The murder of the royal house of David is clearly the deed of Jehu ben Nimshi, and the suggestion that Athaliah murdered her own family has very little credibility. However, Athaliah does take advantage of the situation when she assumes power over Judah. We do not know whether she might have acted simply as a regent for her underage grandson Joash. In any case, the succession of a woman to the throne must have seemed so paradoxical to the Deuteronomistic Historian that he could explain it only by her murdering her own family (p. 298)

Although Fritz does not completely rule out the possibility that Athaliah's assumption of power contains a negative trait, namely a hunger for power, he does not accept the view that Athaliah was a murderer. He does not offer a convincing argument to discredit the claim that Athaliah murdered her own family. Thus, the only argument that attempts to discredit the characterisation of Athaliah as an evil woman is that, as a gebirâ [queen mother], she already had power and therefore had no need of power. Thus, Athaliah could not have been so desperate to get to the throne if she had power and influence as a queen mother. However, if one considers Knight's point above that persons with power often seek and attain more power, such an argument would not sound convincing. In fact, according to textual evidence from 2 Chronicles 22:3, when her son, Ahaziah, was king, she influenced him to become a wicked leader, confirming the power and influence that Athaliah had as the queen mother. This could imply that Athaliah was indeed power hungry as Fritz (2003:298) observes.

Unlike both Fritz and Lee, Smith (1998:150) argues that the $\mathrm{DH}$ had an agenda which sought to portray a monarchy that supported monolatrous Yahwism and eschewed all things foreign, particularly foreign women. Based on such

4.The translation of 11:19; 15:13; 2 Kgs 10:13; Smith 1998:143-145). Olojede (2013:161) also identifies 11.19; $15: 13,2$ Kgs 10:13; Smith 1998:143-145). Olojede (2013:161) also identifies Athaliah as a queen. The expression $g^{e}$ bira carries connotations of power, strength and dominance and probably refers to a great lady or principal lady rather than queen mother, as it is usually translated (Bowen 2001:598). 
a supposed agenda, the negative portrayal of Athaliah by the DH would not come as a surprise. Moreover, if the DH was part of the group that supported Yahwism, portraying Athaliah as a righteous and good leader could have made him unpopular. In fact, it is generally accepted that most of the DH texts support monolatrous Yahwism against Baalism (McKenzie 2009:17; Römer 2009:46-47). ${ }^{5}$ If Athaliah was both a foreign woman and a worshipper of Baal as Jezebel was, she would not have been accepted in a context of Yahwism and an in a context in which foreign women were unpopular. Hence, Athaliah is cast in a negative light by the $\mathrm{DH}$ who was probably a pro-Yahwist.

Smith clearly argues that Athaliah is portrayed in a negative light based on the DH's agenda which sought to depict a monarchy that supported monolatrous Yahwism. By implication, such a view suggests that Athaliah was a good person and was portrayed as a negative person because of the biased agenda. However, this view is unconvincing as the textual evidence shows that Athaliah murdered her own family. As such, the fact that Athaliah was a bad person cannot be disputed, neither should one view the Deuteronomistic historian as biased against Athaliah based on the supposed $\mathrm{DH}$ agenda. In other words, because the DH had an agenda does not mean that Athaliah did not kill the princes.

Dutcher-Walls (1996:112) claims that the condemnation of Athaliah, that is, her characterisation as a murderer and an unsuccessful leader (by implication), was primarily motivated by the fact that she was a woman. For DutcherWalls, the reality that women would find themselves in a subordinate position contributed to the presentation of Athaliah as a mere murderer. However, Smith rejects this claim and puts forward the case of Bathsheba (cf. $2 \mathrm{Sm}$ 11:3). Bathsheba did not receive the kind of condemnation experienced by Athaliah even though she was also a woman. Thus, Athaliah's negative portrait in 2 Kings 11 could not have been based on gender but rather because she worshipped foreign gods (Smith 1998:150). By implication, Athaliah's negative portrait did not stem from patriarchy even though it could have been influenced by patriarchy since there is indeed evidence of patriarchy in the ancient text. Smith's rejection of Dutcher-Walls' claim that the characterisation of Athaliah as a murderer and an unsuccessful leader (by implication) was primarily motivated by the fact that she was a woman is a fair one. In this case, it does not seem that there is convincing evidence that Athaliah was misrepresented or undermined because she was a woman - that she was a victim of patriarchal bias. Thus, it is reasonable to conclude that both Dutcher-Walls' and Lee's allegation that the Deuteronomistic historian showed patriarchal bias in the representation of Athaliah as a bad person is not convincing.

No doubt, there is no convincing argument for a claim that 2 Kings 11 exhibits patriarchal bias towards Athaliah as she was indeed a bad person. Therefore, in a case in which

5.The text of 2 Kings 10:18 shows evidence of monolatry which rejects the worship of Baal and promotes the exclusive worship of Yahweh (Otto 2007:48). Evidence of of Baal and promotes the exclusive worship of Yahweh (Otto 2007:48).
anti-Baalism in 2 Kings 11 is recognised by Dutcher-Walls (1996:126).
Athaliah is exclusively read in the light of her negative side - as merely a murderer - scepticism concerning the presentation of Athaliah as a model in South Africa would be justified. It means that the rejection of Athaliah based on her negative side would be justified as such a side would not provide a commendable example to be held for women to follow in post-apartheid South Africa. However, a perception of Athaliah which exclusively focuses on her negative actions and disregard her positive deeds, which are displayed by her political astuteness, would be a biased one. As such, a critical factor to probe in reconstructing a Deuteronomistic Athaliah is whether or not she was a politically astute leader during her rule. Whether she was good or bad, based on the views examined above, is not the primary concern at this point. In her investigation of the sociological probabilities in the text in question, Dutcher-Walls claims that it is improbable that Athaliah had no support from the group of political elites who had a vested interest in her rule. In other words, Athaliah probably enjoyed the support of a group of elites which is '... invisible in the story world but inevitable in the social world of a monarchy' (Dutcher-Walls 1996:154). Similarly, Branch (2004) argues:

If the Jerusalem nobility negotiated the marriage, then it had too much at stake politically to back out during the turmoil of Jehu's purges and likely supported both her coup and her reign. (p. 546)

If she did enjoy some support in certain circles, it would mean that she demonstrated political astuteness at the time of her reign. Branch notes that the $\mathrm{DH}$ is silent on the agricultural activities, climate, international intrigues or other highlights of the 6 years of Athaliah's reign. Silence, however, does not mean that there was no activity during her rule. If Athaliah was not a politically astute leader, how did she manage to rule for 6 years? ${ }^{6}$ Thus, Branch $(2004: 545,554)$ rightly suggests that ' $[s]$ he must have been politically astute to have survived that long, especially when others - men lasted only weeks or brief years'. In Israel, Shallum ruled for one month (2 Kgs 15:13), Pekahiah reigned for 2 years (2 Kgs 15:23), and Zimri ruled for 7 days (1 Kgs 16:15). In Judah, Amon ruled for 2 years (2 Kgs 21:19), Jehoahaz reigned for 3 months (2 Kgs 23:31) and Jehoiachin ruled for 3 months (2 Kgs 24:8) (Branch 2004:554). It thus seems that Athaliah was a politically astute leader.

More appealing is the argument that Athaliah's was a political alliance. As Branch (2004:546) rightly puts it, '[T]he union of Jehoram and Athaliah evidently eased the tensions between Israel and Judah prevalent since Solomon's time.' Thus, it is reasonable to view Athaliah as a politically astute leader who could unite nations. Furthermore, the fact that the priests of Jerusalem and 'the people of the land' conspired against Athaliah in favour of Joash as king (2 Kgs 11:18-20) is reflected in Ishida's (1977:160-161) argument that Athaliah assumed leadership to maintain political stability rather than to oppose Yahwism. In other words, maintaining the

6.The length of reign of does not automatically mean that the ruler was a good leader neither does it prove successful leadership (e.g., the South African apartheid regime which lasted for years cannot be said to have been a good regime). 
status quo in terms of the reign of the House of Omri was a priority for Athaliah. That status quo was maintained for 6 years while she was in power. Thus, it is reasonable to argue that Athaliah's political astuteness shows that there was at least one woman in the Old Testament who demonstrated the ability to lead a nation.

Besides the rejection of the claims that Athaliah is unfairly presented by the Deuteronomistic historian in 2 Kings 11 and the argument regarding her political astuteness which proves her ability to lead, it is also necessary to point out that Athaliah was the only woman in the history of ancient Israel who ruled the nation. Could it be that patriarchal ideology caused a scarcity of female rulers in ancient Israel as it is the case in the (South) Africa context? The fact that Athaliah was the only woman who led the nation during the monarchical period accounts for a patriarchal bias against women (Masenya [ngwan'a Mphahlele] 2013:142-143). During that period, public life, including the political arena, was maledominated. Valuable as the contributions of female Old Testament scholars such as Masenya (ngwan'a Mphahlele) are with regard to pointing out patriarchal texts, the fact that Athaliah was the only woman who ruled the ancient Israelite state as a queen has not been read in the South-African political context. In other words, the South-African context has not been brought to bear on the text of 2 Kings 11 in such a way that the issue in the modern context, which resonates with the issue in the text, would be brought to light.

Even though Athaliah is portrayed in a negative light, the role she played in ancient Israel is equally worthy of attention and affirmation as is the roles of women such as Miriam, Rizpah or the Wise Woman of Abel. ${ }^{7}$ Olojede (2009:598) is sceptical about casting Athaliah alongside other women who are regarded as political saviours of sorts and who were not murderers like her. However, the fact that Athaliah was politically astute and that she did lead a nation amidst the scarcity of female rulers in ancient Israel merit her recognition, affirmation and elevation as much as other notable women in the Old Testament.

A cardinal question to pose is: Do the issues around the patriarchal nature of the South-African modern context resonate with the possible evidence of patriarchy in the text of 2 Kings 22? Firstly, the perception of Athaliah, which disregards her positive deeds that are displayed by her political astuteness as shown above, bears a striking similarity to how South African society does not view women as suitable presidential candidates though their works are commendable. During the election of the president, the positive work of women such as MlamboNgcuka and Dlamini-Zuma appear to be disregarded as much as Athaliah's positive deeds were disregarded as argued above. Both Athaliah and the preceding women have demonstrated political astuteness. It has been argued that the DH is silent on the agricultural activities, climate, international intrigues or other highlights of Athaliah's reign.

7.For the role played by Miriam, Rizpah and the Wise Woman of Abel, see Branch (2009:28, 36, 60, 69-70).
Secondly and importantly, the striking parallel between the South-African modern context and the context of 2 Kings 11 is that the patriarchal bias against women which is mirrored in the scarcity of female rulers in ancient Israel is similarly observed in the case of (South) Africa. That South Africa has never had a female president confirms the preceding scarcity. Thirdly, Athaliah became a leader in Judah by default: After the death of her son, she was not appointed by the patriarchal ancient Near-Eastern society. The fact that the society did not appoint Athaliah bears striking similarity to the SouthAfrican situation where a female president has never been appointed. The statement by Angie Motshekga reflects the sentiment that the people themselves - the society - are not ready for a female president.

This article set out to present a gender-conscious reading of 2 Kings 11. On the one hand, the undeniable fact that Athaliah killed the princes shows her negative side which may not serve as a good model for women in South Africa. On the other hand, the political astuteness of Athaliah is commendable, especially in a context of patriarchy, that is, a setting in which the dominance of male rulers and the scarcity of female leaders was evident. As such, a reading of Athaliah in light of such astuteness suggests the potential for female empowerment in a context where a woman has never been president, such as South Africa. The preceding reading also challenges the South-African patriarchal society to view women as potential presidential candidates.

\section{Conclusion}

The present article has shown that patriarchy is alive and well in South-African politics as the country has never produced a woman head of state. Angie Motshekga's statement that 'South Africa is not ready to have a female president', which represented the opinion of the ANCWL, has not only suggested that South-African society is still trapped in a patriarchal paradigm, but it also exhibits a failure to address patriarchy. Such patriarchy is further illustrated by both the scarcity of female presidents in (South) Africa and the perception that women are incapable to lead a state. In light of the (South) African context, a gender-conscious reading of 2 Kings 11 was employed to re-read Athaliah.

Most scholars correctly argue that Athaliah was not a good person. However, the worth of her character is not the primary concern of this article. Rather, the emphasis here is on the scarcity of female rulers in ancient Judah which confirms the patriarchal bias against women. Likewise, the scarcity of female heads of states in (South) Africa is undisputable. Athaliah was the only woman who ruled in the history of ancient Judah. Thus, the political astuteness of Athaliah during her rule yields empowering possibilities on two levels for women who have been allocated a secondary role in (South) African politics. Firstly, because such astuteness shows that women are capable of leading nations, women in South Africa need to realise that they are being marginalised in South-African politics. Secondly, all women as well as all men in South Africa need to blow the trumpet louder against 
patriarchy which presents the perception that women are incapable of leading South Africa as president. Women are indeed capable and ready to lead.

\section{Acknowledgements Competing interests}

The author declares that he has no financial or personal relationships which may have inappropriately influenced him in writing this article.

\section{References}

Adejumobi, S.A., 2007, The history of Ethiopia, Greenwood Press, Westport.

African National Congress (ANC), 2014, '12 presidents 100 years: Celebrating 100 years of selfless struggle,' viewed 26 February 2014, from http://www.anc.org.za/ centenary/show.php?id=9330

Arnold, M., 1977, The testimony of Steve Biko, Smith, London.

Baldauf, S., 2012, 'Malawi's Banda becomes Africa's third female head of state', viewed 18 April 2014, from http://www.csmonitor.com/World/Keep-Calm/2012/0407/ Malawi-s-Banda-becomes-Africa-s-third-female-head-of-state

Botta, A.F., 2014, 'What does it mean to be a Latino biblical critic? A brief essay', in F. Lozanda Jr. \& F.F. Segovia (eds.), Latino/a biblical hermeneutics: Problematics, objectives, strategies, pp. 107-120, Society of Biblical Literature, Atlanta.

Bowen, N.R., 2001, 'The quest for the historical Gebira', Catholic Biblical Quarterly 63(4), 597-618.

Branch, R.G., 2004, 'Athaliah, a treacherous queen: A careful analysis of her story in 2 Kings 11 and 2 Chronicles 22:10-23:21', In die Skriflig 38(4), 537-559. http:// dx.doi.org/10.4102/ids.v38i4.448

Branch R.G.,2009, Jeroboam's wife: The enduring contributions of the Old Testament's least known women, Hendrickson Publishers, Peabody.

Cone, J.H., 2005, 'Loving God with our heart, soul, and mind', in I.E. Carruthers, F.D. Haynes III \& J.A. Wright Jr (eds.), Blow the trumpet in Zion: Global vision and action for the 21st century Black church, pp. 59-64, Fortress Press, Minneapolis.

Cowell, A., Kasinof, L. \& Nossiter, A., 2011, 'Nobel peace prize awarded to three activis women', viewed 19April 2014, from http://www.nytimes.com/2011/10/08/world/ nobel-peace-prize-johnson-sirleaf-gbowee-karman.html?pagewanted=all\& $r=0$

Dube, M., 1996, 'Reading for decolonization (John 4:1-42)', Semeia 75, 37-59.

Dube, M., 1999, 'Searching for the lost needle: Double colonization and postcolonial African feminisms', Studies in World Christianity 5, 213-228. http://dx.doi.org/ 10.3366/swc.1999.5.2.213

Dube, M., 2000, Postcolonial feminist interpretation of the Bible, Chalice Press, St Louis.

Dube, M., 2003, 'Jumping the fire with Judith: Postcolonial feminist hermeneutics of liberation', in S. Schroer \& S. Bietenhard (eds.), Feminist interpretation of the Bible and the hermeneutics of liberation, pp. 60-76, Sheffield Academic Press, New York.

Dutcher-Walls, P., 1996, Narrative art, political rhetoric: The case of Athaliah and Joash, Sheffield Academic Press, Sheffield. (Journal for the Study of the Old Testament Supplement 209).

Fiorenza, E.S., 2014, 'Between movement and academy: Feminist biblical studies in the twentieth century', in E.S. Fiorenza (ed.), Feminist biblical studies in the twentieth century: Scholarship and movement, pp. 1-20, Society of Biblical Literature, Atlanta.

Fritz, V., 2003, 1 \& 2 Kings: A continental commentary, Fortress Press, Minneapolis.

Hendricks Jr, O.M., 2005, 'The prophetic imperative: Reclaiming the gospel by speaking truth to power', in I.E. Carruthers, F.D. Haynes III \& J.A. Wright Jr (eds.), Blow the trumpet in Zion: Global vision and action for the 21st century Black Church, pp. 76-85, Fortress Press, Minneapolis.

Horsfield, P., 2013, 'Why Joyce Banda is extraordinary?', viewed 19 April 2014, from http://www.malawivoice.com/2013/08/15/why-joyce-banda-is-extraordinary/

Hunter, Q., 2013, 'No woman president "soon"', The New Age, 08 October 2013, p. 1, viewed 19 February 2014, from http://www.thenewage.co.za/108808-1007-53No_woman_president_soon

Ishida, T., 1977, The royal dynasties in Ancient Israel: A study on the formation and development of royal-dynastic ideology, W. de Gruyter, Berlin. (Beihefte zur Zeitschrift für die Alttestamentliche Wissenschaft 142).
Knight, D.A., 2011, Law, power and justice in Ancient Israel, Westminster John Knox Press, Louisville.

Lemaire, A., 2007, 'West Semitic inscriptions and ninth-century B.C.E. Ancient Israel', British Academy 143, 279-303.

Lee, K.S., 2004, '1 and 2 Kings', in D. Patte (ed.), Global Bible commentary, pp. 105118, Abingdon Press, Nashville.

Lerner, G., 1986, The creation of patriarchy, Oxford University Press, Oxford.

Malala, J., 2012, 'The African union has elected a star in Nkosazana Dlamini-Zuma', viewed 23 April 2014, from http://www.theguardian.com/commentisfree/2012/ jul/18/africanunionnkosazana-dlamini-zuma

Masenya (ngwan'a Mphahlele), M., 2004, How worthy is the woman of worth? Rereading Proverbs 31:10-31 in African-South Africa, Peter Lang, New York.

Masenya (ngwan'a Mphahlele), M., 2008, 'An African-conscious female's reading of Steve Biko', in C.W. du Toit (ed.), The legacy of Stephen Bantu Biko: Theological challenges, pp. 114-155, Research Institute for Religion and Theology, University of South Africa, Pretoria.

Masenya (ngwan'a Mphahlele), M., 2011, 'The woman of worth in Proverbs 31:10-31: Reread through a Bosadi (Womanhood) lens', in F. Tobias, W. Hans-Georg \& M Elke (eds.), Theologie im Kontext von Biographie und Weltbild, pp. 79-96, FranckeBuchhandlung, Marburg.

Masenya (ngwan'a Mphahlele), M., 2012, 'Eating the louse and its larva!: The indignity of poverty as embedded within selected African and Old Testament proverbs', Scriptura 111(3), 452-459.

Masenya (ngwan'a Mphahlele), M., 2013, 'The dissolution of the monarchy, the collapse of the temple and the "elevation" of women in the post-exilic period: Any relevance for African women's theologies?', Old Testament Essays 26(1), 137-153.

McKenzie, S.L., 2009, 'A response to Thomas Römer, "The so-called Deuteronomistic History"', Journal of Hebrew Scripture 9(17), 15-21.

Mtintso, T., 2012, 'The clock is ticking', ANC Today 12(39), 7-9.

Murithi, T., 2012, 'Briefing: The African Union at ten: An appraisal', African Affairs 111(445), 662-669. http://dx.doi.org/10.1093/afraf/ads058

Oduyoye, M.A., 2002, Beads and strands: Reflections of an African woman on Christianity in Africa, Editions Clé and Regnum Africa, Akropong-Akuapem.

Oduyoye, M.A., 2005, 'Women and ritual in Africa', in M. Oduyoye \& M. Kanyoro (eds.), The will to arise: Women, tradition and the Church in Africa, pp. 9-24, Wipf \& Stock, Eugene.

Olojede, F.O., 2009, 'Review of Robin Gallaher Branch (ed.), “Jeroboam's wife: The enduring contributions of the Old Testament's least known women"', Scriptura 102, 597-598.

Olojede, F.O., 2011, 'Unsung heroines of the Hebrew Bible: A contextual theological reading from the perspective of woman wisdom', PhD dissertation, Department of Old and New Testament, University of Stellenbosch.

Olojede, F.O., 2013, 'Chronicler's women: A holistic appraisal', Acta Theologica 33(1), 158-174. http://dx.doi.org/10.4314/actat.v33i1.8

Otto, E., 2007, 'The pivotal meaning of Pentateuch research for a history of Israelite and Jewish religion and society', in J. le Roux \& E. Otto (eds.), South African perspectives on the Pentateuch between synchrony and diachrony, pp. 29-53, T \& T Clark, London.

Republic of South Africa, 2013, 'Women empowerment and gender equality bill', Government Gazette 37005(6), 1-20.

Römer, T., 2009, 'Responding to Richard Nelson, Steven McKenzie, Eckart Otto, and Yairah Amit', Journal of Hebrew Scripture 9(17), 36-49.

Seale, L., 2013, 'SA not ready for female president, say ANC women', Pretoria News, 08 October 2013, p. 1, viewed 19 February 2014, from http://www.iol.co.za/news/ politics/sanotreadyforfemalepresidentancwl1.1589121

Smith, C., 1998, '“Queenship" in Israel?: The cases of Bathsheba, Jezebel and Athaliah', in J. Day (ed.), King and messiah in Israel and Ancient Near East: Proceedings of the Oxford Old Testament seminar, pp. 142-162, Sheffield Academic Press, Sheffield.

Snyman, G., 2010, 'The ethics of reading and the quest for the audience in the Book of Chronicles', Old Testament Essays 23(3), 804-821.

Snyman, G., 2011, 'Looking into black eyes and feel the embarrassment: A selected and selective reading of the Africana Bible', Old Testament Essays 24(2), 1-28.

Tesfu, J., 2014, 'Empress Zewditu (1876-1930)', viewed 19 April 2014, from http:// www.blackpast.org/gah/empress-zewditu-1876-1930

West, G., 2014, 'Locating "contextual Bible study" within biblical liberation hermeneutics and intercultural biblical hermeneutics', HTS Teologiese Studies/ Theological Studies 70(1), 1-10. http://dx.doi.org/10.4102/hts.v70i1.2641

Zuma, J., 2014, 'Full speech: President Jacob Zuma announces members of the National Executive, Pretoria', viewed 23 June 2014, from http://www.sanews.gov. za/south-africa/full-speech-president-jacob-zuma-announces-members-nationalexecutive-pretoria 